\title{
Sweeter offer by Wellcome keeps genome scientist in Britain
}

London \& Washington. Possibly the largest genome research centre in the world may be established in Britain as the result of discussions that are taking place between the Medical Research Council, the Wellcome Trust and John Sulston, leader of the project to map and eventually sequence the genome of the nematode worm Caenorhabditis elegans. The talks end speculation that Sulston and his collaborators on the $C$. elegans project might go to work for the

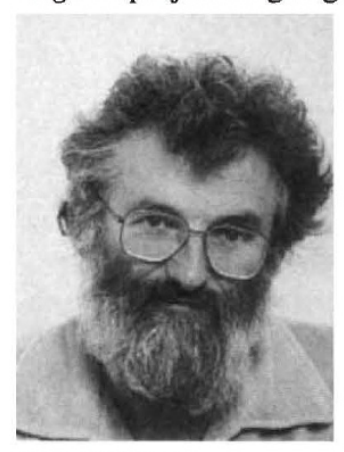

John Sulston

private sector, in particular a gene sequencing company being created by US industrialis t Frederick Bourke (see Nature 355, 483; 1992).

S ulston's group had a threeyear grant, for $£ 2$ million a year (US\$3.5 million), that ended last month, and the MRC has asked the government to renew its funding of the project. That money, if awarded, would follow the nematode project into the new centre.

The Wellcome Trust, one of the largest medical research charities in the world, has yet to decide on the size and details of its contribution, but Michael Morgan, the trust's programme director, said that the sum would be comparable to what is currently being spent on the nematode project. The two funding bodies have set up a joint working party to further plans for the centre. It is hoped that, when established, it will also attract money from elsewhere in Europe.

The core of the centre will be a sequencing facility based on techniques developed by Sulston's group at the MRC's Laboratory of Molecular Biology (LMB) at Cambridge. The group now produces around one megabase of sequence a year for $C$. elegans, and the intention is to extend this to five megabases a year at the new centre, an increase Sulston says is achievable with his group's existing techniques. Such an output would make the centre one of the most prolific in the world.

As well as stepping up activity on the nematode sequencing, the core facility will also work on the human genome, which is a particular interest of the Wellcome Trust. The intention is to make the centre more than a sequencing factory, with other senior scientists joining Sulston to pursue their own research involving selected regions of the human and other genomes. Expertise on informatics will also have a place at the centre, although initial computer support will come from LMB.

It is not known where the centre will be based, although Cambridge is a strong contender. The strong international links that have been a feature of the $C$. elegans project are expected to carry over into the new arrangement. Robert Waterston, a geneticist at Washington University in St Louis, Missouri, is Sulston's principal collaborator. He too is hoping to enlarge his laboratory considerably, and has applied to the US National Institutes of Health for a major increase in funding. Although the two researchers plan to continue a scaled-up C. elegans collaboration, Waterston is not planning to expand into human genome research.

Although the formation of a UK centre would rule out a move by Sulston and his co-workers into the private sector, the possibility of commercialization is not excluded from their plans. "There may be spin-off companies as a result of the focused activity at the centre, but there is unlikely to be any direct commercialization," said Michael Morgan. Direct commercialization would breach the Wellcome Trust's status as a charity.

lan Mundell \& Christopher Anderson

\section{Russians reassure India on rocket contract}

New Delhi. Russia last week told India that it will fulfil its contract to supply cryogenic rocket engines despite having been told by the United States (see Nature 356, 732; 1992) that the contract violates an international agreement to prevent the spread of nuclear technology.

In a visit made to clarify his country's stance on the rocket deal, Gennady Burbuli, Russian secretary of state, said that "neutral international experts" will be examining the contract to establish whether it conforms to the Missile Technology Control Regime (MTCR). Burbuli did not name the experts who will examine the contract or specify when it would be done.

Although it is not a signatory to the regime, Russia has undertaken to abide by its provisions. Burbulis told Indian officials that Russia is also morally bound to fulfil its commitments under the contract, signed in January 1991 . He added that the decision to have the deal examined by neutral experts should be interpreted not as an excuse to renege on the agreement but as proof of
Russia's desire to adhere to the regime.

India wants the cryogenic engines for its Geostationary Satellite Launch Vehicle (GSLV) being developed by the Indian Space Research Organization (ISRO) to launch heavy communications satellites. Its 2,350 million-rupee ( $\$ 80$ million) contract with the Russian space agency Glavkosmos promises to supply it with two cryogenic engines and related technologies that would enable ISRO to build additional engines. The first parts are to be delivered in 1994.

Burbulis's comments have not dispelled India's fears over the fate of the contract. M. R. Rao, chairman of the Indian Space Commission, has admitted that the technology transfer agreement has entered a "difficult" phase. And the prime minister, P.V. Narasima Rao, told parliament last week that "Russia has given all signals of adhering to the contract" but that there remains an element of uncertainty.

Space officials believe that the ISROGlavkosmos contract meets all the obligations of contracting parties under MTCR.
The US objections are seen as a move to cripple the civilian GSLV programme and prevent India from becoming a competitor in the launch business.

India has a well-developed space infrastructure and is one of the few countries with a launch centre near the equator - an ideal location for launching geostationary satellites. The GSLV, once developed, will be available for commercial launches of satellites weighing up to 2.5 tonnes.

ISRO scientists admit that the GSLV programme will be delayed if Russia fails to deliver the engines and transfer the technology. An ISRO project to develop cryogenic engines indigenously was abandoned in 1989 when the Russians made their offer.

"If Russia scraps the deal now, we will have to start all over again" says one ISRO scientist. "And we do not know how long it will take to develop a prototype." He said that ISRO has plans for a non-cryogenic stage that would be heavier and more costly than the existing model if the Russian agreement is cancelled.

K. S. Jayaraman 